\title{
Bánsági Andor*
}

\section{Az SMU 29 tengeralattjáró elfeledett áldozata}

\section{ELŐZMÉNYEK}

Az SMU 29 a német AG Weser műveknél gyártott (UB-II típusú), beltengerekre szánt tengeralattjáró volt. Terveit a német flotta 1915-ben átadta az Osztrák-Magyar Monarchiának, hogy az ne veszítsen időt saját típus kifejlesztésével. Ebből az osztályból 7 db épült (U 27-U 32 és az U 40).

Az U 29-est a Ganz és Társa Danubius Gép-, Waggonés Hajógyár Rt. fiumei gyárában építették, gerincét 1916. március 3-án fektették le, 1916. október 21-én bocsátották vízre és 1917. január 21-én adták át a flottának, aznap szolgálatba is állt.

Parancsnoka, Leo Prásil sorhajóhadnagy korábban az SMU 10 naszádot vezényelte. Az U 29, nem sokkal vízre bocsátása után három brit gőzöst süllyesztett el: 1917. április 10-én a DALTON (3486 BRT) tehergőzöst torpedóval, április 17-én a MASHOBRA (8324 BRT) utasszállító- és tehergőzöst lövegtűzzel és torpedóval, május 19-én pedig a MORDENWOOD (3125 BRT) tehergőzöst szintén torpedóval. A június 17-én induló portyája azonban már nem járt

\section{1. táblázat. Az SMU 29 német UB-II típusú tengeralattjáró} föbb technikai adatai

\begin{tabular}{|l|l|l|}
\hline \multirow{2}{*}{ Vízkiszorítás } & felszínen & $278 \mathrm{t}$ \\
\cline { 2 - 3 } & lemerülve & $312 \mathrm{t}$ \\
\hline Hosszúság & & $37,7 \mathrm{~m}$ \\
\hline Szélesség & $4,37 \mathrm{~m}$ \\
\hline Merülés & felszínen & $\begin{array}{l}2,67 \mathrm{db} \\
\text { Körting motor }\end{array}$ \\
\hline \multirow{3}{*}{ Hajtómú } & víz alatt & $\begin{array}{l}2 \mathrm{db}, 33 \mathrm{~kW}-\mathrm{kW} \text { (45 LE) } \\
\text { villanymotor }\end{array}$ \\
\cline { 2 - 3 } & felszínen & $9 \mathrm{csomó}$ \\
\cline { 2 - 3 } & víz alatt & $4 \mathrm{csomó}$ \\
\hline \multirow{2}{*}{ Sebesség } & $\begin{array}{l}2 \mathrm{db} 45 \text { mm-es torpedóindító, } \\
5 \mathrm{db} \text { torpedókészlet és } \\
1 \mathrm{db} 75 \text { mm-es L/30-as löveg }\end{array}$ \\
\hline \multirow{2}{*}{ Fegyverzet } & & 19 fő \\
\hline Legénység & &
\end{tabular}

ÖSSZEFOGLALÁS: Az SMU 29 tengeralattjáró 1918. április 4-én megtorpedózott egy ellenséges hajót, amit a naszád parancsnoka csak gőzösként azonosított. A hajó neve és típusa azonban egy évszázadon keresztül ismeretlen maradt az osztrák és a magyar történészek számára is. A brit levéltárakban őrzött dokumentumok digitalizálása tette lehetővé az események pontos rekonstruálását, és a hajó beazonosítását. Az áldozat a brit HMS EDGAR védett cirkáló volt. A torpedóvédő dudorral felszerelt hadihajó kisebb sérülésekkel átvészelte a támadást, és zavartalanul befutott Málta kikötőjébe.

KULCSSZAVAK: SMU 29, HMS EDGAR, Leo Prásil, tengeralattjáró, császári és királyi haditengerészet

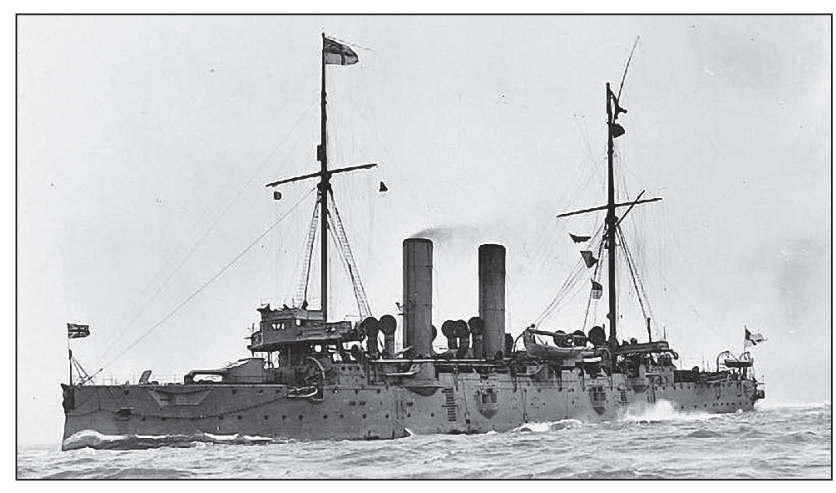

1. ábra. Az HMS EDGAR védett cirkáló

szerencsével, ugyanis június 18-án egy Valona felől érkező repülőgép miatt vészmerülést kellett végrehajtania, majd a gép három bombát is vetett rá. Az U 29-es képes volt folytatni az útját, de egyetlen célpontot sem talált. Július 12-én Pólába ment javításra, ezzel pedig véget is ért számára az 1917-es év, ugyanis 1918 március közepéig nem tudott újabb bevetésre indulni.

A hosszúra nyúlt felújítás után 1918. március 16-án hajózott ki Pólából Cattaróba, majd március 25-én elindult ötödik bevetésére. Március 26-án, a portya második napján, egy olasz romboló megpróbálta legázolni, de sikerült időben lemerülnie. A romboló hajócsavarja ugyan nekiütközött a toronynak, de csak minimális sérüléseket okozott, így folytatta útját a Mediterráneumba. Március 27-én erős viharba került a Jón-tengeren. Április 4-én Máltától délre, a 35²06’ É, $14^{\circ} 24^{\prime} \mathrm{K}$ pontban megtorpedózott egy teherhajót, de annak elsüllyedését nem tudták megerősíteni. Április 5-én sikertelen torpedótámadást hajtott végre egy konvojban haladó gőzös ellen, majd a kísérőhajók hét vízibombát vetettek rá. Április 15-én visszaérkezett a Cattarói-öbölbe.

A magyar nyelvű szakirodalom csak a fenti információkkal rendelkezik az SMU 29 ötödik útjáról, és a 2010-es évekig az osztrák kutatók számára is ismeretlen volt az 1918. április 4-én megtorpedózott hajó. Még William Aichelburg 2002-ben megjelent rendkívül alapos lexikona, a Register der K. (u.) K. Kriegschiffe is csak tehergőzösként hivatkozik rá. A történet csak néhány évvel ezelőtt tisztázódott, miután a brit Nemzeti Levéltár (The National Archives) anyagai elektronikusan is el-

ABSTRACT: On April 4 1918, SMU 29 submarine torpedoed an enemy ship that the gun-boat commander identified only as a steamer. However, the name and type of the ship remained unknown to Austrian and Hungarian historians for a century. The digitization of documents held in British archives has made it possible to accurately reconstruct the events and identify the ship. The victim was the British HMS EDGAR protected cruiser. The warship, equipped with a torpedo bulge, escaped the attack with minor injuries and ran smoothly into the port of Malta.

KEY WORDS: SMU 29, HMS EDGAR, Leo Prásil, submarine, imperial and royal navy

ORCID: 0000-0003-0593-1691 


\section{2. ábra. Az HMS HOPE testvérhajója, az HMS COMET}

érhetővé váltak. Az osztrák Oliver Trulei 2012-ben megjelent Die U-Boot Kommandanten der k.u.k. Kriegsmarine címü könyve már név szerint említi a megtorpedózott hajót: az HMS EDGAR védett cirkáló volt az áldozat.

Az HMS EDGAR a róla elnevezett kilenctagú osztály első egységeként, 1893-ban állt szolgálatba. A háború kitöréséig a kínai hajóraj tagja volt, majd a hadüzenet után a 10. cirkálóraj tagjaként az északi vizeken járőrözött. 1914 végén kiszerelték a fő tüzérségét alkotó $2 \mathrm{db} 24 \mathrm{~cm}$-es ágyút, hogy azokkal az új monitorokat fegyverezzék fel, majd hónapokig a kikötőben állt. 1915 februárjában kapott új fegyverzetet: $10 \mathrm{db} 152$ mm-es ágyúval szerelték fel, valamint - három másik testvérhajójával együtt - kísérleti jelleggel torpedóvédő dudorral látták el. Ezután a Dardanelláknál szolgált, majd 1917-ben átvezényelték az Égei-tengerre.

1918. április 4-én az HMS EDGAR az HMS HOPE romboló kíséretében Máltára hajózott, amikor a jobb oldalán eltalálta az U 29 torpedója. Az események aránylag pontosan rekonstruálhatók, ugyanis április 12-én az HMS EDGAR fedélzetén kihallgatták a cirkáló parancsnokát, valamint a legénység több tagját is. (Az Admiralitás számára 1918. május 24-én készült jelentést a brit Nemzeti Levéltárban őrzik.) A jelentés szerint a torpedót az elvakító napfény miatt - amely felől a torpedó érkezett -, a hajón szolgálatot teljesítő figyelők egyike sem vette észre. A jobb oldali hármas számú (S3) lövegnél csapódott be, és $5^{\circ}$-os dőlést okozott, amit ellenárasztással sikerült megszüntetni. A cirkáló egy lövést adott le a tengeralattjáró feltételezett irányába, hogy így jelezzen a rombolónak. Az HMS HOPE azonnal ráfordult, aktiválta a ködfejlesztőit, majd három vízibombát vetett azon a ponton, ahol számításuk szerint a tengeralattjárónak kellett tartózkodnia.

A jelentésből további érdekességek is kiderülnek: Az HMS EDGAR maximális sebessége mindössze 10 csomó volt, noha új korában még 20 csomó elérésére is képes volt. A romboló egyik turbinája nem működött, így az nem tudott maximális sebességgel haladni. (27 helyett csak 16 csomós sebesség elérésére volt képes.) Az U 29 mintaszerű támadást hajtott végre, ugyanis az őrszemek már csak a torpedó becsapódása előtti másodpercekben vették észre, hogy hajójukat megtámadták. A cirkálónak azonban a szerencse is segített, a torpedóvédő dudor kiválóan vizsgázott. A víz csak két rekeszt árasztott el, míg két másikat folyamatos szivattyúzással vízmentesen tudtak tartani. A kikötőbe érkezés után az összes szivárgást megszüntették.

A vizsgálat másik érdekessége a tengeralattjáró sorsának kérdése, ami minden támadás esetén szóba került. (A jelentések - brit és más ellenséges nemzetek esetén is - általában túlzottan optimisták, rendszeresen fogalmaznak úgy, hogy szinte bizonyos, hogy a tengeralattjáró az elhárító műveletek következtében megsemmisült vagy súlyosan megsérült. Ez azonban a legritkább esetben volt így.) Az HMS HIBISCUS sloop néhány nappal később elhajózott a támadás színhelye mellett. Trafford Martin sorhajóhadnagy, a hajó parancsnoka, vallomásában megemlíti, hogy olajfoltot láttak ott, ahol az HMS HOPE vízibombákat vetett. A folt egy mérföld hosszú volt, és egyes helyeken száz yard széles. Roncsoknak azonban nyoma sem volt. Ennek ellenére a jelentés 5. pontja kijelenti, „lehetséges, hogy a tengeralattjáró megsérült, ha nem is süllyedt el". Ez azonban nem volt igaz.

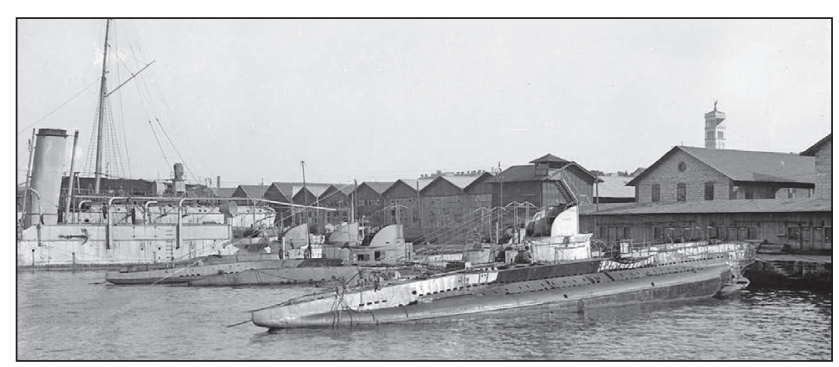

3. ábra. UB-II-es osztrák-magyar tengeralattjárók (köztük az SMU 29) a háború után, Velencében

Az HMS EDGAR elleni támadást követően az U 29 folytatta útját, majd másnap egy torpedót indított a francia VERDUN (2 664 BRT) tehergőzösre, de az nem talált. A tengeralattjáró ötödik portyája április 15-én, 17 órakor ért véget, amikor horgonyt vetett a Gjenovic állomásnál. Leo Prásil sorhajóhadnagy 1918. május 9-én addigi szolgálatáért megkapta az Ezüst Katonai Érdemérmet a kardokkal kitüntetést. Prásil, az U 29-essel június 9-én - az U 27 és U 31 naszádokkal közösen - még részt vett az otrantói tengeri zár elleni nagy támadásban, de mivel az SMS SZENT ISTVÁN csatahajó elsüllyedése miatt Horthy Miklós ellentengernagy a hadműveletet félbeszakította, az U 29 eredménytelenül tért vissza testvérhajóival a Cattarói-öbölbe. Prásil augusztus folyamán betegség miatt kénytelen volt átadni a hajó parancsnokságát Friedrich Sterz sorhajóhadnagynak, majd felépülése után a fiumei Bergudiban építés alatt álló U 51 tengeralattjáró parancsnokának nevezték ki. Mivel a háború végéig a tengeralattjárót nem sikerült befejezni, így ezt a pozíciót már érdemben nem tudta betölteni.

Az HMS EDGAR sorsa az U 29 támadása után meglehetősen eseménytelenül telt. A háború után leszerelték, majd 1921-ben hajóroncsként adták el. 1924. április 24-én érkezett meg Morecambe kikötőjébe, ahol szétvágták. Az SMU 29 Friedrich Sterz parancsnoksága alatt sem torpedózott meg több ellenséges hajót, bár szinte állandóan a tengeren volt. Utolsó portyájáról november elsején tért vissza az U 14 társaságában, azt követően, hogy Horthy Miklós flottaparancsnok a császár utasítására átadta a flottát a délszláv Nemzeti Tanácsnak. A háború utáni osztozkodás során végül az Olasz Királyság kapta meg háborús jóvátételként, de sohasem sorolták be az olasz flottába, mert hajóroncsnak nyilvánították.

$A z$ osztrák-magyar haditengerészet megszűnése után Leo Prásilnak is döntenie kellett az állampolgárságáról és a nemzetiségéről, ami nem volt könnyű számára. A legtöbb tiszt egyszerűen csak annyit válaszolt az ilyen kérdésekre, hogy „En egy k.u.k. tiszt vagyok!” Az új államok tisztviselői ezért a születési hely alapján határozták meg az állampolgárságot és a nemzetiséget. Prásil erre is csak annyit mondott, hogy „Jézus Krisztus egy pajtában született, mégsem lett tehén". Végül az osztrák néphadseregben vállalt tisztséget. 1919 május végéig a grazi tengerész törzsszázadnál szolgált, majd a határőrségnél. Leo Prásil 1924. április 29-én halt meg vérmérgezésben, és május 2-án temették el a grazi Szent Péter temetőben.

\section{FELHASZNÁLT FORRÁSOK}

„Damage by torpedo to H.M.S. EDGAR - ADM 137/3531" - The National Archives, Kew, 1918;

Oliver Trulei. Die U-Boot Kommandanten der k.u.k.

Kriegsmarine. Wien: 2012.;

Greger, René. Austro-Hungarian Warships of World War I. London: Published by lan Allan, 1976. 